\title{
An Appraisal of Decentralization in Ensuring Good Governance: A Case Study on Enemay Woreda in Amhara Regional State, Ethiopia
}

\author{
Getaye Mulugeta Kasse \\ Department of Civics and Ethics Studies, College of Social Science and Humanities, Injibara University, Injibara, Ethiopia \\ Email address: \\ nat.ye.gm2020@gamil.com

\section{To cite this article:} \\ Getaye Mulugeta Kasse. An Appraisal of Decentralization in Ensuring Good Governance: A Case Study on Enemay Woreda in Amhara \\ Regional State, Ethiopia. Journal of Public Policy and Administration. Vol. 4, No. 3, 2020, pp. 29-35. doi: 10.11648/j.jppa.20200403.11
}

Received: June 3, 2020; Accepted: June 19, 2020; Published: August 10, 2020

\begin{abstract}
The main purpose of this article was undertaking an appraisal on the practice of decentralization in ensuring good governance at local level government (here after in Ethiopia Woreda Government). In this respect, the research question revolves around to what extent the existing decentralized power and resources ensuring good (quality) governance. The research method employed to this study is purely qualitative and a cross-sectional descriptive case study research design employed. Accordingly, focus group discussion, key informant interview and field observation were held to collect primary data. Besides, the Wereda directives, plans, strategies, and annual reports used as primary sources. The finding of the study shows a mixed outcome. In one hand, owing to decentralization different local governance institutions, associations are establishment. However, the process of ensuring good governance under a decentralized system in the study Woreda is yet far from desirable that is undermined by skilled personnel constraints, low capacity in terms of planning and implementation, lack of full-fledged autonomy, lack of leadership skills, and corrupted officials in the study area. Therefore, the researcher forward as a solution like woredization, strong auditory system, making open discussion with the society, capacity building so as to fill the leadership gap and extensive awareness creation is needed.
\end{abstract}

Keywords: Good Governance, Decentralization, Local Government, Governance

\section{Background of the Study}

\subsection{Introduction}

Decentralization and good governance are not new concept, and indeed, they have been worked as a policy tools in many developing countries for decades. Accordingly, in Ethiopia, decentralization has the aim to make peaceful co-existence among peoples and granted local self-rule [12]. The reciprocal relationship between them is expressed through its implicit objective of decentralization is to ensure good governance, service delivery, poverty alleviation and sustainable development. However, the relevant issues is not the formal existence of decentralized structure but rather the extent and its ramification of decentralization has become a tool for ensuring good governance at local government. Therefore, this research focused on practice and challenges of decentralization to ensure good governance at district
(Woreda) level government in Ethiopia.

\subsection{Statement of the Problem}

Since 1991, Ethiopia has embarked on a serious of decentralization process devolving considerable power, resource and responsibilities to the regions and lower district level governments in an attempt to ensuring good governance, democratization and development [17]. According to [14], the motive behind decentralization in Ethiopia is to ensure good governance, even if, other several sources argue on that its motive is political by which it maintain one economic unit.

Nevertheless, decentralization did not achieve enough in establishing locally responsive, transparent, accountable, efficient and participatory local government; which has the capability of addressing the problem that the country has been continuously humiliated by the lack of good governance [4]. Ensuring good governance as the aim of decentralization still yet not adequately addressed [5]. Eminent federalism 
student Elazar confirmed as without democratization at local government, mere decentralization is produced "decentralized despotism" [2].

Even if, some research has already been done, a lot remain to be done [12]. Empirical investigation with regard to service provider accountability, public participation in planning and decision-making and its structural set up is needed [12]. As academic evidences and survey of the existing literatures also reveal that researches conducted on the impact of decentralization in facilitating good governance are still largely sketchy or not adequately conducted.

Thus, by taking into consideration the above stating problem, the researcher firmly believed that the need to conduct an appraisal by identifying one woreda administration. Therefore, based on the above stated problem, the researcher provides the following research questions to be answered:

1. Does the prevailing decentralization help to ensure good governance in the study area?

2. What kind of institutional setting established for effective decentralization in the study area?

3. To what extent the local leaders are accountable and responsible to their local community?

4. To what extent the study Woreda community empowered through planning, decision-making, implementations and evaluations in their own local affairs.

\subsection{Objective of the Study}

\subsubsection{General Objective}

The general objective of this research is to make trend analysis on the prevailing decentralized power and resources ensure good governance in Enemay Wereda and its challenge.

\subsubsection{Specific Objectives}

1. To assess the achievements and challenges of decentralization in ensuring good governance in the study area.

2. To identify mechanisms and institutional setting of local government to realize effective decentralization to ensure good governance in the study area.

3. To assess the awareness and commitment of local community to deliver effective decentralization in the study Woreda.

\subsection{Delimitation of the Study}

Both decentralization and good governance are ample and jargon words. Because of it lacks conceptual precision, researcher show the inclusion criterion in this research. Thus, the status of good governance is measured through the prevailing power and resources devolution decentralization by taking rule of law, accountability, transparency, quality leadership, community participation, inclusiveness, effectiveness and efficiency and access and quality public service delivery as a parameter.

\section{Conceptual and Theoretical Framework}

\subsection{Decentralization: Theoretical Exposition}

To find precise and universally accepted definition for decentralization lead fraught with problems [1]. The why question of such conceptual precision problem is confirmed by Paulos [8] as:

This includes methodological problems related to language, measurability and difficulty of differentiating between degrees of decentralization within a single country, different usage of the term in different context and complexity of the use of decentralization which have many forms and several dimensions.

The term decentralization is a multidimensional and ample concept in which different scholar literatures understand the term differently [8]. Decentralization means different things to different people [1]. Thus, scholars in the area give their own theoretical kits as narrower and broader sense. Decentralization in its broader sense begins with Rondinelli and defines decentralization as:

“...transferring or delegating of legal and political authority to plan, make decisions and manage public functions from the central government and its agencies to field organizations of those agencies, subordinate units of government, semi-autonomous public corporations, areawide or regional development authorities; functional authorities, autonomous local governments, or nongovernmental organizations" [10].

But his earlier definition criticized as it excludes private decentralization since decentralization now embraces political, fiscal, and administrative and market (private) dimensions [8, 9] also argues that decentralization is dismantling or downsizing central government power by increasing local participation in democracy and strengthening local government. Besides this, [7] define decentralization as "legal acts and administrative measures that transfer responsibility and authority, resources, accountability and rules from central government to local entities".

\subsection{Good Governance: Conceptual Exposition}

As far as the meaning of the concept is concerned, it can be said that an exact interpretation of the concept of governance is still elusive. It means, the term good governance does not have single and exhaustive definition, nor is there a delimitation of its scope, that commands universal acceptance. Rather, it has a multi-dimensional theoretical formulation among researchers, despite having universal acceptance of its importance. However, there are various interpretations in its concept.

In contrary to mal-governance, good governance is epitomized by predictable, open and enlightened policy making, professional ethos of bureaucracy, striving for public good, transparent and accountable processes, and a strong civil society participating in public affairs [18].

More or less, similar meaning also given by $U N D P$ as 
participation, transparency, rule of law, effectiveness, equitable, accountability are some of the manifestations of good governance; by which it answer the socio-economic and political demands of the community and the voice of the poorest and the most vulnerable are heard in decision making over the allocations of development resource [15].

\subsection{Decentralization and Good Governance Vinculum}

Beyond their multi-dimensional and an elusive concepts, both decentralization and good governance have their own linkage by which its objective of decentralization and elements of good governance.

Accordingly, UNDP [13] try to show mutual relationship by stating that decentralization is the logical application of the core characteristics of good governance at the subnational and local levels. These characteristics include like accountability, transparency, rule of law and responsiveness, inclusiveness. This statement infers that without decentralization, good governance seems to be unsuccessfully implemented. Similarly, [16], confidently says that when effective decentralization and democratic local governance advance in tandem, local governments - and the communities they govern - gain the authority, resources, and skills to make responsive choices and to act on them effectively and accountably.

Of course, there is a doubt on theoretical prediction like [3] argued that, "empirical result have not always been as robust as theory would predict, drawing in to questions theoretical linkages that lead from decentralization to good governance" [3]. But [5] debates against the ideas' of Grindile [3] as "a democratic local government that is accountable to the people and that enhances public participation in governance is a sine qua non for effective decentralization". [13] Also shortly also underlines the decentralization is a means to ensure good governance by bringing responsibilities and capacities to the lower level of government.

Because of decentralization, local voters (citizens) have more information on how local governments perform their duties and responsibilities than national or regional government, competitive elections give them rewards or punish those now directly responsible to administration and public service [3]. For [11] also, decentralization is enable to provide institutional framework to make decision-making closer to the people, and building partnership and synergies among actors and organizations at many levels to achieve economic and human development goal.

\subsection{Decentralization and Its Phases in Ethiopia Governance System Post 1991}

Since 1991, decentralization has been fundamental in Ethiopia. Despite its dispute on the beginning of decentralization, some indigenous scholars argue that, decentralization drive in Ethiopia has two phases. According to [12] decentralization program in Ethiopia has first and second wave that the first wave of decentralization covered from 1991-2001 and the second wave onwards of this time.
Accordingly, the first wave of decentralization, despite its significant achievements like both federal and regional government have their own legislative, executive, and judiciary government branches, introducing fiscal decentralization; the decentralization jurisdiction was limited or curtailed on regions and it was not genuine and adequate for local government since decentralization most matter [12].

The time for 2001 creates circumstances that the federal government motivated for further devolution of power and resources to lower local governments [6]. Accordingly, the motive behind further decentralization is to promote good governance, community participations, create socioeconomic development at local government Paulos [8].

\section{Research Method and Methodology}

\subsection{Study Area Description}

Enemay Woreda is one of the 20 woredas of East Gojjam Zone in Amhara National Regional State. It has 25 kebeles and Bichena is the administrative center of the woreda which is located at 265 kilometers far from capital city. Based on figures of 2007 population census, the woreda has a total population of 188,447 of whom 93,418 are men and 95,059 are women.

\subsection{Research Method}

The researcher used descriptive research design in which the researcher examined the extent of decentralized power and resources to ensure good governance and the research questions require descriptive way (what is going on) instead of why is it going on. Furthermore, in a qualitative research, the researcher plays a pivotal role in constructing concepts, and principles out of details of discussions, interviews and observations.

\subsection{Source of Data, Sample Size and Sampling Techniques}

As primary source, the target institutions and respondents were assessed through key informant interview, focus group discussion and field observation like public meeting, delivered public services with first hand impressions and insights.

The researcher selected 18 key informant interviewees that mean at least two informants from each target group with regard to issue required classification and justification. The study used purposive sampling techniques to select those sample respondents since it is the most commonly acceptable tool to select the key informants and focus group discussants. Thus, the researcher used his own judgment/ purposive way to select the data respondents by taking in to consideration of having first-hand knowledge and stakes about the issues.

\subsection{Tools and Procedures of Data Collection}

In line of the above sampling techniques and based on stated reason (above), the researcher used key informant interviewees, and focus group discussion and field 
observation. The procedure used for these data collection tools as present as follows:

The researcher used key informant interviewees with people who know what is going on in the community. The purpose of key informant interviews was to collect information from a wide range of people; among others it including community leaders, experts, sector officials, executives and councils at different level.

The main aim of focus group discussion was to increase the reliability and validity of qualitative data. These focus group discussions conducted with the community of three kebeles that have both good and low performance in their executing and one group from Woreda administrators. Those three Kebeles were Telima, Yetemen and Addiss Alem. So, a total of four group discussion were held and those participants were selected purposively by taking due account certain experiences, responsibilities and knowledge about the practice of decentralized power and authority and good governance.

Field observation was also another additional tools and data collection mechanism; by which the researcher visited some necessary and required places and events. The researcher attended at public meeting at three kebeles that is Yetimen, Adiss Alem and Dima kebele. In addition, the researcher attends cabinets and sector office meetings at Woreda administration.

\subsection{Data Analysis and Presentations}

The data collected from key informant interviewees, focus group discussion participants, field observations and the study Woreda document review analyzed qualitatively. During the time of data presentation and analysis, the researcher used all the necessary steps and required material that is good for qualitative research like content analysis; that means making recurrent themes and narratives were applicable.

\section{Data Result and Discussion}

\subsection{Profile of Key Informant and Group Discussants}

As the next table stipulate, three-fourth of the interviewees were above grade ten, to Msc degree holders. In terms of age, the whole key informants were ranged from 20-59. Besides, the social status is from public officials- that is administrator, professionals, employees, councils, ordinary community members, unemployed, youth, and community elders.

Table 1. Profile of Key Informants in the Study Area.

\begin{tabular}{|c|c|c|c|c|c|c|c|c|c|c|c|}
\hline \multirow{2}{*}{ No } & \multirow{2}{*}{\multicolumn{2}{|c|}{ Social Status }} & \multirow{2}{*}{$\begin{array}{l}\text { No of } \\
\text { informants }\end{array}$} & \multicolumn{2}{|c|}{ Sex } & \multicolumn{6}{|c|}{ Educational Level } \\
\hline & & & & $\mathbf{M}$ & $\mathbf{F}$ & Illiterate & $5-10$ & 10 complete & Diploma & Degree & MA/Msc \\
\hline \multirow[b]{2}{*}{1} & \multirow{2}{*}{ Woreda } & Council & 2 & 1 & 1 & & & & 1 & 1 & \\
\hline & & Cabinets & 2 & 2 & & & & & & 1 & 1 \\
\hline \multirow{2}{*}{2} & \multirow{2}{*}{ Kebele } & Council & 2 & 1 & 1 & & 1 & 1 & & & \\
\hline & & Cabinets & 3 & 2 & & & 1 & 1 & & & \\
\hline 3 & Experts & & 2 & 1 & 1 & & & & 1 & 1 & \\
\hline 4 & Employe & & 3 & 1 & 2 & & & 1 & 1 & 1 & \\
\hline 5 & Ordinary & Imunity & 2 & 1 & 1 & & 1 & & 1 & & \\
\hline 7 & Justice Ir & tion & 2 & 2 & & & & & 1 & 1 & \\
\hline Total & & & 18 & & & & & & & & \\
\hline
\end{tabular}

Source: Own Field Data; 2018.

\subsection{Administrative Structure and Organization}

The study Woreda is composed of 24 rural and semi-urban kebeles and its administrative centre is Bichena. On wards of 2001 E. C, those rural kebeles separate its administration and the urban administration is known as Bichena Town Administration. Thus, the rural and semi-urban kebeles are known as EnemayWoreda Administration.

The three branches of government establish both at Woreda and kebele administration level. Members of Woreda council are elected from each kebeles based on population size of each kebeles. At kebele level also, each kebele has its own kebele council. The Woreda executing power is given for 24 sector offices such as education, health, justice, Youth, culture and sport office, civil service, police, security affairs and finance sector office are among others.

\subsection{Involvement of Community Participation}

Regarding community participation through different affairs, the researcher collected data from all key informants, focus group discussion, and field observation. As the data shows, insignificant number of key informants revealed the study woreda community participates through different ways and institutional associations like Female Development Association, Youth Development Association, and Elders Development Association, Member of Kebele Education Board. Subsequently, same informants disclosed again, the community participate a day meeting within each month to evaluate the performance of the kebele administration and their own affairs. The result of FGD also spectacles there are occasions like election meeting, NGOs organized meeting, voluntary community work meeting are some participation engagement of the community.

Sources found from Woreda Education Office reveal that there is community participation in school construction, irrigation or security and through different means such as finance, labor and material support. Many studies also endorsed that the community can participate in development activities through financial contribution, problem identification, decision-making, implementing and evaluation 
of development program.

Nonetheless, this does not mirror the existence of real and inclusive participation. As the majority key informants, FGD and field observation confirms, majority of the people are not committed to participate owing to lost trust on government in relation to mal-governance. Majority of the key informants revealed in a way that, participating through association or other ways are mere symbolic.

\subsection{Governance Accountability and Responsiveness}

Majority of the key informants and focus group discussion uncovered the lack of accountability and responsiveness of the local office holders in a way that people have faced various problems of favoritism, patronage and corruption at public institutions.

With regard to responsiveness of the local government, key informants were asked, FGD and field observation were held whether public officials and different institutions are listening to the demands and voices of community. The data obtained from public office key informants revealed that, the government is highly responsible for the demands and voice of the woreda community. Those informants further stated different bureau officials goes down to the grass root level and discuss with community about their demands, service problems, and local security issues and others issues.

However, the majority of key informant and field observation resulted; the government is much passive to give a response, while the community faces many problems. For instance, one key informant discloses severity of water problem facing in one kebele. As the researcher observed and FGD stated, the government officials have been silent for more than seven month consecutively and yet not unsolved. Even, the officials had not been programmed the public meeting to hear the community voice. Further FGD result shows, the government is unresponsive because of public officials and administrators does not have the skills and capacity to carry out new programs and respond the woreda community demand.

\subsection{Complaint Management System}

The study revealed that majority of the interviewees; group discussants show public officials does not listen and take account of their voice. But, small number of the interviewees and some other group discussants agreed on the existence of compliant management mechanisms through the Woreda. They revealed that, the Woreda community can complain the decision making or governance system through public meeting, social justice and complain management offices.

However, majority of the key informants and group discussants revealed that, there is an absence of simple procedures and appropriate time frame for action given to ensure fair and swift action on complaints, suggestions and grievances by the public in a sustainable manner. Moreover, all such complaints do not treat fairly. Usually, compliant solutions is given by relatives, friends or/and position in the Woreda administration. For instance, as the researcher field observation revealed, if someone who have complain on vacancy related to exam mischief, the compliant does not obtain a solution at Woreda civil service office rather he/she goes to a regional civil service office for complain. Over all, field observation of the researcher revealed that complaint management system is yet far from desirable.

\subsection{Transparency and Free Flow of Information}

In this regard, some of the key informant stated, there is an open communication system with the public, woreda government institutions and other development partners. According to them, different institution are formed like community policing, justice reform program, government communication office are some of formal institutions by which different actors obtain information about government activities. Besides, the government is open allocating and distributing different plans, strategies, and directives through printed materials to the community.

However, most of key informants and focus group discussion results blame the fairness and openness of those established institution. Beyond their openness and fairness, the information they obtain has a problem of accessibility and quality. Key informants and group discussant revealed "information that we get about government is more exaggeration and more limited that explain through different reports of the community demand coverage and specification."

\subsection{Fairness and Equity, Inclusiveness and Representation}

Albeit, key informants of officials told they fairly treat the community, majority of the key informants and focus group discussion at three kebeles disclose that the woreda government is highly unfair and unequal treatment of citizens. According to key informants, the problem/unfairness is reflected through discrimination of individuals in land provision, employment opportunities, political appointments, discrimination of the adult to be elected through different institutional leaders, equally treated before law, unfair public service provision, are obviously practiced through woreda governments. In addition, data gained from FGD expose that leaders at different levels enforce the community over taxation and financial fees without the consultation of community.

The researcher also conducted an interview, group discussion on inclusiveness and representation of different groups in the political system. Information obtained from key informant revealed as, "even if the legal framework put the need to be equal representation through different institution of disadvantage groups, in practice, the woredas' government still does not create a practical opportunities particularly, for poor and disabled groups. Even in practice, females at the study woreda are not still adequately and equally participate and gain institutional representation with male. Also, document review and field observation shows the formerly neglected groups (disabled, women, and youth) still practically excluded from representation of political system 
except woreda and kebele council.

\subsection{Performance of Basic Service Delivery}

Field data revealed that, even if, significant improvement have seen recorded through education and health care service provision, there is relatively high problem on access and quality of other public services like electricity, rural road, water services. The interviews with key-informants from government institutions, NGOs, focus group discussion show that the efficiency of the local governance system leaves much to be desired. The dissatisfaction with the effectiveness of these institutions can be traced back to the following reasons: lack of cooperation among local institutions, lack of funds, lack of planning capacity and lack of field structures and misuse of the woreda budget. For instance, as one of the key informants from public service providers states as follows;

"Take water itself. We have the ample water resource but our people cannot access its benefits. If you take every kebeles, there isn't adequate water supply to these kebeles. The regional government is responsible for this problem because of whatever work programs that are prepared have not been formulated in such a manner as to serve our people. Those work programs are irregular or inefficient since it mismatch with the Woreda context and does not provide adequate budget".

With little exception, majority of key informants and focus group discussant evaluated the current service provision through wored's put in to negative terms. As the researcher engaged an interview with key informants, they state that "there is a high shortage of water supply, electricity, road construction, hospitals, and high schools. For instance, only three rural kebelss out of 25 kebeles obtain electricity, two high school in the woreda, the main road still does not covered with asphalt, and high shortage of rural road coverage and there is no hospital and doctors in the woreda. "

\section{Conclusion and Recommendation}

\subsection{Conclusion}

As field data revealed, despite power and resources devolved, institutions established and performance public service provision by the Woreda governments, tremendous challenges still facing the Woreda to ensure good governance and development. It is important to note that a lot of key informants, group discussion, field observation and document review revealed this challenges. The summary of the key finding of challenges therefore are presented as follows.

Existing experience identifies that, there is a lack of community participation through socio-politico as well as economic affairs. This is due to weakness in institutionalizing of public participation, lack of improving community awareness, empowered the Woreda community are root cause.

The study revealed that, there is high non-equitable treatment among Woreda communities. Even if, the woreda civil service reform is good by its legal provision, there is no practical implementation in its human resource development. The policy reform comes to crack while implementing. When the reform implement, there is a high extent of corruption in the sense of favoritism to fill the civil servant vacant position.

With respect to leadership skill and attitudinal change in relation to the change witnessed in working habit, developing better working behavior, community respecting, and developing workable plan and strategies, there is a great problem in the study Woreda. Woreda leaders reflect sense of dictatorship behavior, non-cooperative behavior and trying to monopolize every decision-making process is at momentum.

\subsection{Recommendations}

Based on the above key findings, the researcher forwards the following recommendations as solutions to create effective decentralization to ensure good governance in the study area.

1. To realize practical, effective and inclusive community participation, the Woreda administrators, experts, professionals or stakeholders should create open dialogue, joint actions and mobilizing the community.

2. The Woreda administration should hear the community demand, voice or priorities. It require lot of public meeting to uncover the day to day affairs of the communities.

3. The policies and strategies which come from higher level should consider the Woreda socio-cultural context that is woredazation. It enables that to identify the priorities of communities and raise public confident on their government, keep their culture, values and have a sense of ownership in local affairs.

4. Even though the civil service reform has its own positive impact on the Woreda, it has limitations in its implementation process that is vacancy applicants treated unfairly and unjust way. Thus, the Woreda administration should give greater attention on it to strengthen its human resources and parallel to ensuring justice.

5. Continuous or intensive training in order to create competent and skillful Woreda leaders or public servants is needed. The training should have an impact assessment.

6. The Woreda council committee should go up to Kebele level to oversight the cabinet's performance since the cabinet exaggerated their report and it should be continuous within a fixed period of time.

7. Establish strong auditory system; it enables each sector use its allocated budget wisely and a given period of time.

8. Finally, the researcher recommends that further empirical research is needed in the study area.

\section{Conflict of Interests}

The author has no declared any conflict of interests. 


\section{References}

[1] Dhurba. P. (2001) Decentralization and good governance. India: Delhi. Adroit publishers.

[2] Elazar, D. J. (1987). Exploring federalism. University of Alabama Press.

[3] Grindle, M. S. (2007). Going local: decentralization, democratization, and the promise of good governance. Princeton University Press.

[4] Kassahun B and Tegegn G. (2004). "The Role of Decentralized Governance in Building Local Institutions in Regional Development Dialogue", vol. 25, No. 1, spring 2004.

[5] Mehret A. (2002). Decentralization in Ethiopia. Two Case Studies on Devolution of Power and Responsibilities in Local Government Authorities. In Ethiopia: The challenge of Democracy from Below, (eds), Baharu Zewude and Siegfried Pausewang. Uppsala: NordiskaAfrikanistitiut; Addis Ababa: Forum for Social Studies.

[6] Mulugeta Debeb. (2012). Decentralization in Ethiopia: Concept and Process. The Case of Dendi District, West Shoa Zone of Oromia State. Dissertation Submitted to University of Dortmund. Germany.

[7] Olowu D. and Wunsch J. (2004). "Local Governance in Africa: The Challenge of Democratic Decentralization," Lynne Rienner Publishers, Boulder,

[8] Paulos C. (2007). Clientelism and Ethiopia's Post-1991 Decentralisation. The Journal of Modern African Studies, 45 (3), 355-384.

[9] Ribot, J. C. (2002). African decentralization: local actors, powers and accountability. UNRISD.
[10] Rondinneli, D. A. (1981). 'Government Decentralization in Comparative Perspective: Theory and Practice in Developing Countries', International Review of Administrative Sciences XLVII (2): 133-45.

[11] Shabbir. (2005). Building Democratic Institutions: governance Reform in Developing Countries. USA. Kumarian Press.

[12] Taye and Tegegne G. (2007) "Decentralization and Changing Local and Regional Development Planning in Ethiopia." In. Fukui, E. Kurimoto, and M. Shigeta (eds) Ethiopia in Broad Perspective: Papers of the $8^{\text {th }}$ International Conference of Ethiopian Studies Vol. 3, lcyoto: shokado Book Sellers.

[13] UNDP. (1998) Decentralized Governance Monograph: A Global Sampling of Experiences, Management Development and Governance Division, Bureau for Policy Development.

[14] UNDP. (2002). Country Paper- Ethiopia Paper Presented at the Fifth African Governance: Forum on Local Governance for Poverty Reduction in Africa, Maputo, Mozambique (23-25 May).

[15] UNDP. (1997). Decentralized Governance Programme: Strengthening Capacity for People -Centered Development, Management Development and Governance Division, Bureau for Development Policy.

[16] USAID. (2000). The Role of Community Development and Citizen Engagement Activities in Strengthening Civic Engagement and Government Responsiveness in Serbia. Development Initiative Group.

[17] World Bank. (2001). The Woreda Studies (main phase) http:/www.Worldbank.org/afr/et/reports/2001woreda.

[18] World Bank. (2004). Ethiopia: The Emerging Challenge, Public Expenditure Review, Volume I. Washington, D.C. 